\title{
Survival and factors associated with mandibular overdenture fractures with immediate loading
}

Cleice Luizi da Silva ${ }^{a}$, Danielle Bezerra de Farias ${ }^{b}$, Maria de Fátima Trindade Pinto Campos ${ }^{c}$, Laércio Almeida de Melo ${ }^{b}$, Maria Angela Fernandes Ferreira ${ }^{d}$, Adriana da Fonte Porto Carreiro ${ }^{d}$

\section{ABSTRACT}

OBJECTIVE: Survival rates of mandibular overdentures on two implants retained by bar-clip system with immediate loading and the factors related to fractures was analyzed.

METHODS: Twenty-three subjects were followed for 32 months. Fracture occurrence was the outcome variable, while the thickness of denture base, maxillomandibular space and masticatory efficiency comprised the independent variables.

RESULTS: The survival rate was $49.5 \%$, with $34.7 \%$ of fractures. There was no association between the independent variables and fractures.

CONCLUSION: So, the risk of mandibular overdenture fractures with immediate loading is high Furthermore, masticatory efficiency, thickness of the denture base and maxillomandibular space did not influence the incidence of fractures.

Keywords: dentures; dental prosthesis; dental implants; immediate loading.

\section{Sobrevida e fatores associados a fraturas de sobredentaduras inferiores com carga imediata}

\section{RESUMO}

OBJETIVO: A taxa de sobrevida de sobredentaduras mandibulares com dois implantes retidas por sistema barra-clipe com carga imediada e os fatores associados a fraturas foram analisados.

METODOLOGIA: Vinte e três indivíduos foram acompanhados por 32 meses. A ocorrência de fratura foi a variável dependente, enquanto a espessura da base da prótese, o espaço maxilomandibular e a eficiência mastigatória compreendeu as variáveis independentes.

RESULTADOS: A taxa de sobrevida foi de $49,5 \%$, com $34,7 \%$ de fraturas. Não houve associação entre as variáveis independentes e as fraturas.

CONCLUSÃO: Assim, o risco de fraturas de sobredentadura mandibular com carga imediata é alto. Além disso, a eficiência mastigatória, a espessura da base dentária e o espaço maxilomandibular não influenciaram na incidência de fraturas

Palavras-chave: dentadura; prótese dentária; implantes dentários; carga imediata.
Department of Dentistry, Federal University of Rio Grande do Norte, Natal, Brazil

${ }^{\mathrm{b}}$ Specialist Prosthodontist, Federal University of Rio Grande do Norte, Department of Dentistry Natal, Brazil

Specialist Prosthodontist, PhD Student, Department of Dentistry, Federal University of Rio Grande do Norte, Natal, Brazil

d Professor, Department of Dentistry, Federal University of Rio Grande do Norte, Department of Dentistry Natal, Rio Grande do Norte, Brazil 


\section{INTRODUCTION}

Mandibular overdentures are susceptible to fractures. Factors associated with such fractures such as occlusal forces, thickness of the prosthesis base, porosity and contamination of the acrylic resin have been described in previous studies $[1,2]$. In general, available studies in literature only evaluate the survival of implants in users of mandibular overdentures, overlooking the survival of the prosthesis $[3,4]$. Moreover, those studies investigating the survival of mandibular overdentures and factors associated with fractures do not standardize the number of implants, the type of restraint system, and have not studied overdentures with immediate loading $[5,6,7]$. In this sense, the objective of this study was to evaluate survival rates of mandibular overdenture on two implants retained by bar-clip system with immediate loading and identify whether masticatory efficiency, thickness of the denture base and maxillomandibular space influence the occurrence of fractures.

\section{METHODS}

\section{Study design, location and population}

This is a prospective cohort study conducted between the period of January 2011 and April 2014. This study was conducted at the Department of Dentistry, Federal University of Rio Grande do Norte (UFRN), and approved by the institution's committee under number 970.713. The study included 23 subjects ( 3 males and 20 females), rehabilitated for at least three months with upper full conventional dentures (FCD) and mandibular overdenture retained by bar-clip system with immediate loading. Two implants were inserted into the jaw with external hex platforms or cone morse Neodent ${ }^{\circledR}$ Titamax (Neodent, Curitiba, Brazil; diameter $3.75 \mathrm{~mm}$, length $11 \mathrm{~mm}$ ). Individuals who had lost at least one implant, had their overdentures changed into fixed prostheses or no longer used the lower overdenture were excluded from the study.

\section{Measurement}

\section{Survival rates}

The total usage time of the prosthesis and the occurrence moment of fracture were recorded on a case report form. Participants were followed for a period of 32 months.

\section{Thickness of overdenture base}

This was determined with the aid of a Conventional Manual Specimeter (Millenium/Wilcos, Brazil industry). On the right side of the clip, one end of the specimeter was placed on the inside part/edge of the prosthesis and the other end placed on the outside part/edge.

\section{Maxilomandibular space}

We used a bow divider (Jon, São Paulo, Brazil) and a millimeter ruler. One of the ends was placed on the implant platform and the other touching the incisal edge of the upper
FCD lateral incisor. The distance between the two points was measured with a millimeter ruler.

\section{Masticatory efficiency}

This was performed by colorimetric method for measuring absorbance $(a b s)^{8}$. For data analysis we used the difference between the masticatory efficiency of conventional full dentures and the masticatory efficiency three months after conversion of conventional full dentures into lower overdentures.

\section{Statistical analysis}

Statistical analysis was performed based on the SPSS 20.0 software for Windows. Kaplan-Meier method was used for the overdenture survival analysis. Student T-test was used to assess whether there was a difference between the occurrence of fracture averages and the independent variables analyzed in the study.

\section{RESULTS}

The sample consisted of 23 subjects with a mean age of 57.6 years. 8 fractures were observed, corresponding to $34.7 \%$ of total overdentures in a period of 32 months.

Observing the survival analysis over time, the probability of fracture increased considerably from the first fracture event. The survival rate was initially $91.3 \%$, declining to $49.5 \%$ at the end of the curve. The survival curve did not show a continuous and rapid decline over time, indicating that the fracture event occurred with high frequency. Eight fracture events were observed, two of which occurred in the interval between 1 and 3 months (Figure 1).

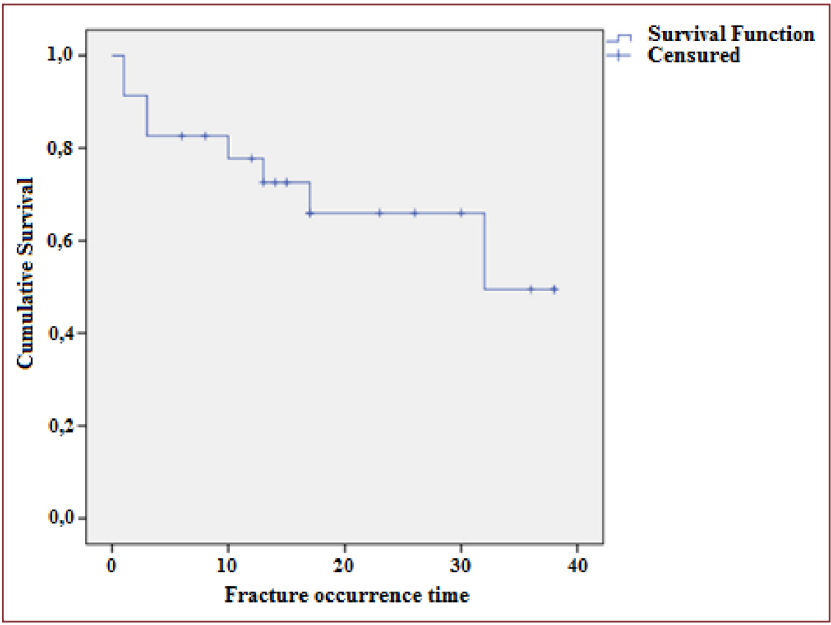

Figure 1. Cumulative survival rate $x$ fracture occurrence time (month)

By evaluating the factors related to fractures, masticatory efficiency, thickness of the denture base and maxillomandibular space did not influence the occurrence of fractures $(p>0.05)$. However, the difference between the averages of masticatory efficiency and the occurrence of 
fracture remained at the significance threshold $(\mathrm{p}=0.078)$. Those individuals who had higher average masticatory efficiency had higher occurrences of overdenture fractures (Table 1).

Table 1. Averages, standard deviation and $p$ values found through student T-test.

\begin{tabular}{lccc}
\hline & \multicolumn{2}{c}{ Fracture } & P value \\
\cline { 2 - 3 } & Yes & No & \\
Maxillomandibular space $(\mathrm{mm})$ & $13.87 \pm 2.10$ & $12.4 \pm 2.77$ & 0.204 \\
Thickness of the base $(\mathrm{mm})$ & $4.08 \pm 1.32$ & $3.81 \pm 1.18$ & 0.617 \\
Masticatory efficiency (abs) & $0.40 \pm 0.045$ & $0.11 \pm 0.11$ & 0.078 \\
\hline
\end{tabular}

\section{DISCUSSION}

This study aimed to evaluate survival rates of mandibular overdenture on two implants retained by bar-clip system with immediate loading and the factors associated with fractures.

The survival at 32 months was found to be approximately half of the cases, with a high index of fractured overdentures. An earlier study which evaluated the survival of lower overdentures supported by 1 or 2 implants reported survival rates of those supported by two implants of $93.2 \%$, with $9.3 \%$ of fractured overdentures [5]. This difference can be explained by the fact that this study used lower overdentures with immediate loading, unlike the previous study found in the literature, which did not use immediate loading. In rehabilitation with immediate loading, a conventional prosthesis is converted into overdenture by resin clip capturing by adding resin directly, which does not occur in rehabilitation with conventional load where resin around the clip is pressed. Furthermore, in rehabilitation with immediate loading, wearing is performed on the prosthesis base to accommodate the bar and clip. These facts can weaken the base of dentures, which explains the low survival rate and high incidence of fracture in this study.

There was no influence of masticatory efficiency, thickness of the denture base and maxillomandibular space in the incidence of fracture in this study. With respect to the thickness of the base of overdentures, a previous study comparing different base thicknesses of overdentures in the incidence of fractures verified this association [2]. In the present study, the fact that the base thickness of overdentures did not influence the occurrence of fractures can be explained by the low variability of base measurements among users of overdentures. A minimum amount of wear was done to accommodate the bar and the clip, which explains this low variability. In the study in which we found an association, the thickness varied greatly between groups. This fact was only possible because it is a laboratory study, which lets you apply high variation in thickness. The same can be observed in relation to maxillomandibular space, which can also be explained by the low variability of the space between research participants.

In relation to masticatory efficiency, the difference between the averages remained at the significance threshold $(p=0.078)$, with larger fractures in individuals with higher average of masticatory efficiency. This result could most likely become significant with an increase in sample size.

Due to the high incidence of fractures and the low survival rates of overdentures retained by 2 implants and bar-clip system with immediate loading, for this type of rehabilitation we suggest strengthening the base of these prostheses with a metal mesh based on a simplified technique.

\section{CONCLUSION}

It can be concluded that the survival rate of lower overdentures retained by 2 implants and bar-clip system with immediate loading is low. Furthermore, although the risk of fracture for such rehabilitation is high, masticatory efficiency, thickness of the denture base and maxillomandibular space did not influence the incidence of fracture.

\section{ACKNOWLEDGEMENTS}

We would like to thank the Neodent company for donating the implants, which certainly contributed to this study.

\section{REFERENCES}

1. Andreiotelli M, Att W, Strub J. Prosthodontic Complications with implants overdentures: a systematic literature review. Int J Prosthodont 2010;23: 195-203.

2. Fajardo R, Pruitt L, Finzen FC, Marshall GW, Singh S, Curtis DA. The effect of E-glass fibers and acrylic resin thickness on fracture load in a simulated implant-supported overdenture prosthesis. J Prosthet Dent 2011;106: 373-7. https://doi.org/10.1016/S0022-3913(11)60150-9

3. Zancope K, Simamoto Júnior PC, Davi LR, Prado CJ, Neves FD. Immediate loading implants with mandibular overdenture: a 48-month prospective follow-up study. Braz Oral Res 2014;28:313-8. https://doi.org/10.1590/18073107BOR-2014.vol28.0030

4. Vercruyssen M, Marcelis K, Coucke W, Naert I, Quirynen M. Long-term, retrospective evaluation (implant and patient-centred outcome) of the two-implants-supported overdenture in the mandible. Part 1: survival rate. Clin Oral Implants Res 2010;21:357-65. https://doi.org/10.1111/j.16000501.2009.01849.x

5. Gonda T, Maeda Y, Walton JN, MacEntee ML. Fracture incidence in mandibular overdentures retained by one or two implants. J Prosthet Dent 2010;103:178-81. https://doi.org/10.1016/S0022-3913(10)60026-1

6. Cakarer S, Can T, Yaltiric M, Keskin C. Complications associated with the ball, bar and Locator attachments for implant-supported overdentures. Med Oral Patol Oral Cir Bucal 2011;16:953-9. https://doi.org/10.4317/ medoral.17312

7. Bilhan R, Geckili O, Mumcu E, Bilmenoglu C. Maintenance requirements associated with mandibular implant overdentures: clinical results after first year of service. J Oral Implantol 2011;37:697-704. https://doi.org/10.1563/ AAID-JOI-D-10-00096

8. Santos CE, Freitas O, Spadaro ACC, Mestriner-Junior W. Development of a colorimetric system for evaluation of the masticatory efficiency. Braz Dent J 2006;17:95-9. https://doi.org/10.1590/S0103-64402006000200002 